\title{
The thrombophilic network of autoantibodies in celiac disease
}

\author{
Aaron Lerner ${ }^{1 *+}$, Nancy Agmon-Levin ${ }^{2 \dagger}$, Yinon Shapira ${ }^{2}$, Boris Gilburd ${ }^{2}$, Sandra Reuter ${ }^{3}$, Idit Lavi ${ }^{4}$ \\ and Yehuda Shoenfeld ${ }^{2}$
}

\begin{abstract}
Background: Celiac disease is a life-long autoimmune condition, affecting genetically susceptible individuals that may present with thromboembolic phenomena. This thrombophilia represents a puzzle with multiple constituents: hyperhomocysteinemia, B12 and \or folate deficiency, methylenetetrahydrofolate reductase mutations, and protein C and $\mathrm{S}$ deficiency due to vitamin K deficiency. However, the well known thrombogenic factors, antiphosphatidylserine/prothrombin and antiprothrombin have never been explored in celiac disease.
\end{abstract}

Methods: The serum autoantibody levels were determined in 248 individuals, classified into three groups. Group 1 comprised 70 children with definitive celiac disease (age: $7.04 \pm 4.3$ years, male to female ratio 1.06) and group 2 comprised 88 normal children (age: $6.7 \pm 4.17$ years, male to female ratio 0.87 ), representing controls. The pediatric populations were compared to group 3, which included 90 adults who were family members (parents) of group 1 (age: $34.6 \pm 11.35$ years, male to female ratio 1.2). Antibodies were checked by enzyme-linked immunosorbent assay.

Results: Mean optical density levels of serum antiphosphatidylserine/prothrombin immunoglobulin $G$ antibodies were $32.4 \pm 19.4,3.6 \pm 2.5$ and $16.1 \pm 15.8$ absorbance units in groups 1,2 and 3 respectively $(P<0.0001)$, with $45.7 \%$, $0 \%$ and $7.8 \%$ of groups 1,2 and 3 respectively positive for the antibody $(P<0.01)$. Mean optical density levels of serum antiphosphatidylserine/prothrombin immunoglobulin $\mathrm{M}$ antibodies were $14.2 \pm 8.7,6.7 \pm 6.4$ and $12.4 \pm 15.5$ absorbance units in groups 1, 2 and 3 respectively $(P<0.0001)$, with $7.1 \%, 3.4 \%$ and $9.9 \%$ of groups 1,2 and 3 positive for the antibody. Mean optical density levels of serum antiprothrombin and antiphospholipid immunoglobulin $\mathrm{G}$ antibodies were higher in groups 1 and 3 compared with $2(P<0.005)$ and in groups 1 and 2 compared with $3(P<0.01)$, respectively. Groups 1,2 and 3 were positive for antiphospholipid immunoglobulin $G$ antibodies (groups 1 and 2 compared with 3 ). Celiac disease sera harbor a higher antiprothrombin immunoglobulin $\mathrm{G}$ level compared with controls.

Conclusions: It is suggested that the intestinal injury, endothelial dysfunction, platelet abnormality and enhanced apoptosis recently described in celiac disease are at the origin of the increased exposure of phospholipids or new epitopes representing autoantigens. Those autoantibodies might play a pathogenic role in the thrombophilia associated with celiac disease and represent markers for potential anticoagulant preventive therapy.

Keywords: Antiphosphatidylserine/prothrombin, Autoantibodies, Celiac disease, Hypercoagulability, Phospholipid, Prothrombin

\footnotetext{
* Correspondence: lerner_aaron@clalit.org.il

${ }^{\dagger}$ Equal contributors

${ }^{1}$ Pediatric Gastroenterology and Nutrition Unit, Carmel Medical Center, B.

Rappaport School of Medicine, Technion-Israel institute of Technology,

Michal St. No 7, Haifa 34362, Israel

Full list of author information is available at the end of the article
}

\section{Biomed Central}

(c) 2013 Lerner et al.; licensee BioMed Central Ltd. This is an Open Access article distributed under the terms of the Creative Commons Attribution License (http://creativecommons.org/licenses/by/2.0), which permits unrestricted use, distribution, and reproduction in any medium, provided the original work is properly cited. 


\section{Background}

Celiac disease (CD) is the most common autoimmune food intolerance in the world. It is a life-long autoimmune condition [1] mainly of the gastrointestinal tract, affecting the small intestine of genetically susceptible individuals. Environmental factors are crucial for disease induction. Gluten, which is the storage protein of wheat and its alcohol-soluble gliadins are the offending inducers of the disease together with structurally related molecules found in barley, rye and oat. Tissue transglutaminase (tTG) is the autoantigen against which the abnormal immune response is directed [2] and two main autoantibodies, antiendomysium and anti-tTG, are currently the most useful serological markers to screen for the disease $[3,4]$. The sequential chain of events operating in the disease was recently unraveled, and gives hope for future therapeutic strategies [5]. Furthermore, the epidemiology, prevalence and clinical presentation of $\mathrm{CD}$ are changing constantly and, with time, new clinical presentations are depicted that increase the clinical variability of CD [6].

It has been shown that the classical intestinal clinical picture of malnutrition, chronic diarrhea and nutritional deficiencies are disappearing and extraintestinal presentations are emerging. Skin, endocrine, skeletal, hepatic, hematological, gynecological, fertility, dental and behavioral abnormalities are often described [7-9]. Nowadays, we are witnessing an epidemiological shift in the disease phenotype toward a more advanced age, and increased prevalence of latent, hyposymptomatic or asymptomatic presentations [6].

A newly explored area of $C D$ is hypercoagulability and the resulting thromboembolic phenomena. There is an increase risk of stroke in adults and children with $C D$ [10-15]. Thrombophilia, pregnancy loss, deep vein thrombosis, small bowel infarction, atrial fibrillation, Budd-Chiari syndrome, portal and splenic vein thrombosis, and cardiovascular disease have been described [16-21]. Even the onset of the disease may be due to a thrombotic event $[11,17,21]$. Hyperhomocysteinemia with related vitamin deficiency in untreated $C D$, the frequency of methylenetetrahydrofolate reductase variants and the high homology between factor XIII and tTG add to the hypercoagulable status in patients [21-26].

In fact, there is an increased incidence of autoimmune diseases in CD $[1,7,27,28]$. Two examples associated with thrombophilia are systemic lupus erythematosus (SLE) and antiphospholipid (aPL) syndrome [29,30]. Three autoantibodies associated with the two entities are antiphosphatidylserine/prothrombin (aPS/PT), aPL and antiprothrombin (aPT). aPS/PT and aPL autoantibodies confer increased risk for thromboembolic events and poor outcome in those diseases [31-39]. The correlation between aPS/PT antibodies and clinical manifestations of aPL syndrome and the importance of aPS/PT as a marker for this syndrome are well established. The relationship between aPS/PT antibodies and hypercoagulability state is further strengthened by their increased incidence in cerebral infarction [40]. aPT autoantibodies are prevalent in SLE and aPL syndrome and are associated with thrombosis and pregnancy morbidity [41-44].

Despite the coexistence of $\mathrm{CD}$ and thromboembolic events, the aPS/PT and aPT status has never been investigated and aPL activity has scarcely been investigated in CD. On the above backgrounds of aPS/PT, aPT and aPL antibodies and thrombophilia, hypercoagulability in CD, and increased incidence of SLE and $\mathrm{aPL}$ in $\mathrm{CD}$, the presence of aPS/PT, compared with aPL, aPT and anticardiolipin antibodies, were explored in children with $\mathrm{CD}$ and their parents, compared with pediatric controls. Increased incidence of aPS/PT IgG in the celiac group and intermediate incidence in their parents, compared with none in the control group, was detected. Additionally, higher rates of activities of aPS/PT IgM and prothrombin IgG autoantibodies in the celiac patients compared with the other two groups were detected. It seems that the presently studied thrombophilic autoantibodies are operative in CD, extending the hypercoagulability network in this disease.

\section{Methods \\ Study populations}

Serum aPS/PT, aPT and aPL autoantibodies levels were determined in 248 individuals, divided into three groups. Group 1 comprised 70 Israeli children with definitive CD (age 7.04 \pm 4.3 years, male to female ratio 1.06). Group 2 was represented by 88 normal children (age $6.7 \pm 4.17$ years, male to female ratio 0.87 ) as controls. The pediatric populations were compared with group 3, which included 90 family members (parents) of group 1 (age $34.6 \pm 11.35$ years, male to female ratio 1.2).

The following information was collected on the three groups: diet - gluten-containing or gluten-free; symptoms abdominal pain, short stature, vomiting, diarrhea, anemia, failure to thrive and IgA deficiency; familial diseases - CD, diabetes mellitus type 1 or 2, familial Mediterranean fever, inflammatory bowel disease, thyroid disease; laboratory parameters - complete blood count, biochemical profile, IgA levels, CD serology (see ELISA assays below).

$\mathrm{CD}$ was diagnosed according to the revised criteria of the European Society for Pediatric Gastroenterology and Nutrition, based on specific serology and duodenal biopsies [45]. All the participants were on a gluten-containing diet and were checked for celiac serology.

\section{ELISA assays}

\section{Celiac serology}

Three ELISA assays are included in our celiac screening algorithm, as recently described $[4,46]$. Briefly, The AESKU celiCheck (Aesku.Kipp Institute, Wendelsheim, 
Germany) determines IgA and IgG neo-tTG antibodies, those antibodies against the new epitopes created in the transformed complex of gliadin-tTG. In this study, we evaluated The AESKU CeliCheck Neo-epitope assay on the TRITURUS analyzer (GRIFOLS SA, Barcelona Spain). All the participants were additionally screened for tTG IgA assay on the Liaison (DiaSorin, Saluggia, Italy) and the ORGENTEC tTG IgA plus IgG assay on the ETI-MAX 3000 analyzer (DiaSorin). National external quality assessment site is routinely used as the external quality control program.

\section{Anticardiolipin, phospholipid, prothrombin and aPS/PT essays}

Sera were tested for anticardiolipin, phospholipid, prothrombin and aPS/PT antibodies using solid phase enzyme immunoassay (AESKULISA, AESKU diagnostics ( Aesku. Kipp Institute, Wendelsheim, Germany), according to the manufacturer's protocol.

Briefly, serum samples were diluted 1:100 and incubated in microplates coated with the specific antigen. Binding was detected by antihuman immunoglobulins peroxidase (conjugate) and 3,3',5,5'-Tetramethylbenzidine-substrate. The sera was identified as positive for the antibodies according to the manufacture's equations for cut-off value determination or using other cut-offs as specified below:

Cardiolipin check - The immunoassay employed highly purified cardiolipin plus native human beta2-cardiolipin 1 for the combined quantitative and qualitative detection of IgA, IgM and IgG antibodies against cardiolipin in the sera. Positive cut-off was $>24 \mathrm{U} / \mathrm{ml}$.

Phospholipid IgG and IgM - As for the cardiolipin check except for the use of antihuman IgG and IgM peroxidise. Positive cut-off for both antibodies was $>18 \mathrm{U} / \mathrm{ml}$.

Prothrombin IgG - The immunoassay employed highly purified prothrombin (factor II) for the combined quantitative and qualitative detection of IgG antibodies against prothrombin in the sera. Antihuman IgG peroxidase conjugate was employed. Positive cutoff was $>18 \mathrm{U} / \mathrm{ml}$.

\section{Phosphatidylserine/prothrombin IgA, IgG and IgM -} The immunoassay employed highly purified phosphatidylserine plus native human prothrombin for the combined quantitative and qualitative detection of IgA, IgM and IgG antibodies against PS/PT in the sera. Antihuman IgA, IgG and IgM peroxidase conjugates were used. Positive cut-off for PS/PT -IgA was $>28 \mathrm{U} / \mathrm{ml}$. The manufacturers cut-off is $18 \mathrm{U} / \mathrm{ml}$. Based on multiple determinations on 92 healthy Israeli participants, a higher cut-off of the mean plus two SD was used. The receiver operating characteristic curve data were: area under the curve 0.855; standard error 0.0315; 95\% confidence interval 0.791, 0.905; Z statistic 11.258; and $P<0.0001$.

\section{Endoscopy and intestinal histology}

All patients in group 1 underwent esophagogastroduodenoscopy using a GIF-xp 20 endoscope (Pentax, Tokyo, Japan). At least five biopsies were obtained: four from the second part of the duodenum for the diagnosis or exclusion of $\mathrm{CD}$ and one from the antrum.

The biopsies were immediately fixed in buffered formalin and embedded on edge in paraffin. Sections were stained with hematoxylin-eosin and Giemsa, analyzed by the pathologist and graded according to Marsh criteria, as previously described [3]. On the day of endoscopy, $5 \mathrm{ml}$ of peripheral blood was withdrawn, centrifuged at $5000 \mathrm{c} / \mathrm{s}$ for 10 minutes, and the serum frozen in $-80^{\circ}$ Celsius until assayed for serology.

The ethical committee of Carmel Medical Center approved the study and written informed consent was obtained from the parents or guardians of the children.

\section{Statistical analysis}

Data analysis was performed using the PASW 18 statistical package (PASW, Chicago, IL, USA). A comparison of the levels of anticardiolipin, phospholipid, prothrombin and aPS/PT autoantibodies between the three study groups was performed by a Kruskal-Wallis test. For multiple comparisons between any two study groups, a Mann Whitney test was used. For examining the association between the positive cut-offs for all antibodies with the study groups, a Chi square test or exact test for small sample was used. All $P$ values were two-sided, and statistical significance was defined as $P<0.05$.

\section{Results}

No epidemiological statistical difference between the pediatric groups (groups 1 and 2) was detected. None of the participants were IgA deficient and all were screened also by IgG-tTG antibodies. None of the parents (group 3 ) at the time of the study had positive serology for CD, despite consuming gluten. No correlation was found between parents and children concerning the results.

Table 1 shows the mean \pm SD and median of the different autoantibodies in group 1 (pediatric CD), group 2 (pediatric control) and the parents of group 1. Table 2 shows the mean of percentage positivity of the optical density of the autoantibodies in group 1 (pediatric CD) and group 3 (parents) compared with the healthy controls, group 2.

\section{Discussion}

The main result of the present study is the increased incidence of aPS/PT IgG in the celiac group and intermediate incidence in their parents, compared with none 
Table 1 Mean and median of autoantibodies' activity in celiac children, their parents compared to pediatric controls

\begin{tabular}{|c|c|c|c|c|c|c|}
\hline \multicolumn{6}{|c|}{ Mean \pm SD (median) } & \multirow{2}{*}{$\begin{array}{l}\text { Autoantibodies/ } \\
\text { groups }\end{array}$} \\
\hline $\begin{array}{l}\text { Parents versus } \\
\text { pediatric control }\end{array}$ & $\begin{array}{l}\text { Pediatric celiac disease } \\
\text { versus pediatric control }\end{array}$ & $\begin{array}{l}\text { Pediatric celiac } \\
\text { disease versus } \\
\text { parents }\end{array}$ & $\begin{array}{l}\text { Pediatric control } \\
(\mathrm{N}=88)\end{array}$ & $\begin{array}{l}\text { Parents } \\
(\mathrm{N}=90)\end{array}$ & $\begin{array}{l}\text { Pediatric celiac } \\
\text { disease }(N=70)\end{array}$ & \\
\hline ND & ND & $* *$ & ND & $10.7 \pm 13.6(8.2)$ & $7.9 \pm 9.5(5.6)$ & aPS/PT IgA \\
\hline$* *$ & $* *$ & ** & $3.6 \pm 2.5(3.3)$ & $16.1 \pm 15.9(12.3)$ & $32.4 \pm 19.5(27.7)$ & aPS/PT IgG \\
\hline$* *$ & $* *$ & $* *$ & $6.7 \pm 6.4(4.9)$ & $12.4 \pm 15.5$ (8.6) & $14.2 \pm 8.7$ (12.9) & aPS/PT IgM \\
\hline * & $* *$ & $*$ & $11.9 \pm 15.8(6.0)$ & $12.4 \pm 18.2(7.9)$ & $15.2 \pm 19.5(10.6)$ & Prothrombin lgG \\
\hline$* *$ & $* *$ & $* *$ & $9.4 \pm 7.0(8.6)$ & $8.0 \pm 10.4(5.8)$ & $10.4 \pm 6.0(9.1)$ & Phospholipid lgG \\
\hline ND & ND & * & ND & $3.9 \pm 6.9(1.7)$ & $3.3 \pm 2.8(2.5)$ & $\begin{array}{l}\text { Phospholipid } \\
\text { IgM }\end{array}$ \\
\hline NS & NS & $* *$ & $5.5 \pm 3.4(4.9)$ & $2.9 \pm 2.1(2.2)$ & $4.5 \pm 2.6(4.4)$ & Cardiolipin check \\
\hline
\end{tabular}

${ }^{*} P<0.001$; ${ }^{*} P<0.0001$; aPL: antiphospholipid; aPS/PT: antiphosphatidylserine/prothrombin; aPT: antiprothrombin; Ig: immunoglobulin; ND: not done NS: non-significant; SD: standard deviation.

in the control group. Secondary results are the increased rates of aPS/PT IgM and prothrombin IgG autoantibodies in the celiac patients compared with the other two groups. Of note is the constant, parallel, gradual decrease of the levels of aPS/PT IgG and IgM across the continuum of the three groups, from celiac children, to their parents, to pediatric controls. The fact that none of the parents had positive celiac serology points to a potential genetic influence on the presence of aPS/PT autoantibodies. In fact, being an autoimmune disease with a well-established genetic susceptibility and increased familial predisposition, the increased presence of autoantibodies and autoimmune diseases in first-degree relatives of $\mathrm{CD}$ patients is well known [47-49] and aPS/PT should be added to the list. Additionally, aPS/PT should be added to the increasing list of autoantibodies associated with CD-affected patients $[27,28]$.

Despite the fact that many of the autoantibodies might present an epiphenomenon, it is suggested that mainly aPS/PT, but also antithrombin and aPL autoantibodies, are pathogenic and play an active role in $\mathrm{CD}$ pathogenesis and complications. The presence of aPS/PT is directly related to thromboembolic events in aPL syndrome, SLE and cerebral infarction [31-40]. The thrombogenic properties of aPS/PT correlate with increased thrombin generation in aPL syndrome, contributing to the understanding of the pathophysiology of thrombophilia in these patients [36]. Those autoantibodies are strong risk factors for venous thromboembolism in patients with SLE because they induce activated protein $\mathrm{C}$ resistance [37]. The other two IgG autoantibodies, namely antithrombin and aPL, are also associated with thrombotic events in aPL syndrome and SLE [32,33,50,51], and are risk factors for myocardial infarction in middle-aged men $[52,53]$.

The pathophysiology of the thromboembolic phenomena associated with CD [10-26] represents a puzzle with multiple constituents: hyperhomocysteinemia; B12 and lor folate deficiency; methylenetetrahydrofolate reductase mutations; the high homology between blood coagulation factor XIII and tTG; and protein $\mathrm{C}$ and $\mathrm{S}$ deficiency due to vitamin $\mathrm{K}$ deficiency [21-26,54]. The present study unravels a series of autoantibodies, aPL, $\mathrm{aPT}$ and mainly aPS/PT, that form part of this puzzle and are suggested to play a pathogenic role in the thrombogenicity of $\mathrm{CD}$.

Phosphatidylserine is a regular constituent of the inner leaflet of the cell membrane, which is only exposed on the outside of the cell membrane during apoptosis or because of damaged endothelial cells [55]. It is known that prothrombin and aPL antibodies bind specifically to the surface of apoptotic cells [56,57]. Recently, Ieko

Table 2 Percentage positivity of autoantibodies in celiac children and their parents compared with pediatric controls

\begin{tabular}{|c|c|c|c|c|c|}
\hline$P$ & $\begin{array}{l}\text { Pediatric controls } \\
(\mathrm{N}=\mathbf{8 8})\end{array}$ & $\begin{array}{l}\text { Celiac disease parents } \\
(\mathrm{N}=90)\end{array}$ & $\begin{array}{l}\text { Pediatric celiac disease } \\
(\mathrm{N}=70)\end{array}$ & $\begin{array}{l}\text { Optical density cut-off } \\
\text { levels }\end{array}$ & $\begin{array}{l}\text { Autoantibodies positivity/ } \\
\text { groups }\end{array}$ \\
\hline$<0.9$ & ND. & 3.3 & 4.3 & $>28$ & aPS/PT IgA \\
\hline$<0.0001$ & $0^{* * * * *}$ & $* * * 7.8, * *$ & $45.7^{* * *}$ & $>28$ & aPS/PT IgG \\
\hline $0.23>$ & 3.4 & 9.9 & 7.1 & $>28$ & aPS/PT IgM \\
\hline $0.5>$ & 14.9 & 11 & 17.1 & $>18$ & Prothrombin lgG \\
\hline $0.07>$ & *12.5 & *3.3 & 11.4 & $>18$ & Phospholipid IgG \\
\hline $1>$ & ND. & 2.2 & 1.4 & $>18$ & Phospholipid IgM \\
\hline 1> & 0 & 1.1 & 0 & $>24$ & Cardiolipin check \\
\hline
\end{tabular}

${ }^{*} P<0.05,{ }^{* *} P<0.01,{ }^{* * *} P<0.0001 ;$ aPS/PT: antiphosphatidylserine/prothrombin; aPT: antiprothrombin; Ig: immunoglobulin. 
et al. [58] reported that aPS/PT IgG recognizes prothrombin bound to phosphatidylserine on platelets and endothelial cells and, directly or via Fc-gamma receptors, activates a variety of procoagulant agents. However, the complementary aspects of $\mathrm{CD}$ are endothelial dysfunction [59], platelet abnormalities [60,61] and increased apoptosis [62]. Thus, it is suggested that intestinal injury, endothelial dysfunction, platelet abnormalities and enhanced apoptosis cause increased exposure of phospholipids or new epitopes, which are the origin of aPT, aPL and aPS/PT autoantibodies. Those antibodies might play a pathogenic role in the thrombophilia associated with $\mathrm{CD}$.

New light was recently shed on the inflammation coagulation crosstalks' [63]. Recent studies have unveiled molecular underpinnings of the intimate interconnection between both systems. Being a classical inflammatory state, CD can present such crosstalks, resulting in enhanced coagulability in the intestinal arena and on the systemic level. Because there are several pathways of mucosal injury, autoantigens like phospholipids, phosphatidylserine and prothrombin are exposed, inducing the production of aPS/PT, aPL and aPT antibodies. With their thrombogenic capacities, those autoantibodies can present the first or an additional hit in the thrombogenic background operating in CD. Because of the increased coagulability in $\mathrm{CD}$ and the harmful potential consequences, patients positive for those antibodies should be considered to receive preventive anticoagulant therapy.

\section{Conclusions}

We detected increased incidence of aPS/PT IgG in the pediatric celiac group and intermediate incidence in their parents, compared with no incidence in the control group. Additionally, higher rates of activity for aPS/PT IgM and prothrombin IgG autoantibodies were observed in the patients with $\mathrm{CD}$ compared with the other two groups. Based on the extensive literature of thromboembolic phenomenon described in $\mathrm{CD}$, it seems that the thrombophilic autoantibodies studied here are operative in $\mathrm{CD}$, extending the hypercoagulability network of the disease. The use of the autoantibodies described in this study as potential markers for thromboembolic manifestations in $\mathrm{CD}$ is a subject for future exploration.

\section{Abbreviations \\ aPL: Antiphospholipid; aPS/PT: Antiphosphatidylserine/prothrombin; aPT: Antiprothrombin; CD: Celiac disease; ELISA: Enzyme-linked immunosorbent assay; Ig: Immunoglobulin; SD: Standard deviation; SLE: Systemic lupus erythematosus; tTG: Tissue transglutaminase.}

\section{Competing interests}

The authors declare that they have no competing interests.

\section{Authors' contributions}

$A L, N A-L$ and $Y S h o$ conceived of the study, and participated in its design and coordination and drafted the manuscript. YSha and BG carried out all the immunoassays. SR supervised the laboratory analysis and directed the information processing. IL analyzed the data and performed the statistics. All authors read and approved the final manuscript.

\section{Author details}

'Pediatric Gastroenterology and Nutrition Unit, Carmel Medical Center, B. Rappaport School of Medicine, Technion-Israel institute of Technology, Michal St. No 7, Haifa 34362, Israel. ${ }^{2}$ The Zabludowicz Center for Autoimmune Diseases, Sheba Medical Center, Tel-Ashomer 52621, Israel.

${ }^{3}$ Aira e.v./Aesku.Kipp Institute, Mikroforum Ring 3, Wendelsheim 55234, Germany. ${ }^{4}$ Carmel Medical Center, Epidemiology and Community Medicine, Michal St. No 7, Haifa 34362, Israel.

Received: 16 October 2012 Accepted: 11 January 2013

Published: 4 April 2013

\section{References}

1. Lerner A, Blank M, Shoenfeld Y: Celiac disease and autoimmunity. Isr J Med Sci 1996, 32:33-36

2. Reif $S$, Lerner $A$ : Tissue transglutaminase - the key player in celiac disease: a review. Autoimm Rev 2004, 3:40-45.

3. Shamir R, Eliakim R, Lahat N, Sobel E, Lerner A: ELISA assay of anti endomysial antibodies in the diagnosis of celiac disease: comparison with immunofluorescence assay of anti endomysial antibodies and tissue transglutaminase antibodies. Isr Med Assoc J 2002, 4:594-596.

4. Rozenberg O, Lerner A, Pacht A, Grinberg M, Reginashvili D, Henig C, Barak M: A novel algorithm for childhood celiac disease serological diagnosis based upon intestinal biopsies. Crit Rev Allerg Immunol 2012, 42:331-341.

5. Lerner A: New therapeutic strategies for celiac disease. Autoimmun Rev 2010, 9:144-147.

6. Lerner A: Factors affecting the clinical presentation and time diagnosis of celiac disease: The Jerusalem and the West Bank-Gaza experience. Isr J Med Sci 1994, 30:294-295.

7. Branski D, Ashkenazy A, Frier S, Lerner A, Dinari G, Faber J, Bujanover Y, Jonas A, Lebental E: Extra intestinal manifestation and associated disorders of celiac disease. In Gluten-Sensitive Enteropathy from Gastrointest Res. Edited by Branski D, Rozen P, Kaganoff MF. Basel, Switzerland: Karger; 1992:164-175

8. Zelnik N, Pacht A, Obeid R, Lerner A: Range of neurological disorders in patients with celiac disease. Pediatrics 2004, 113:1672-1676.

9. Blazina S, Bratanic N, Campa AS, Blagus R, Orel R: Bone mineral density and importance of strict gluten-free diet in children and adolescents with celiac disease. Bone 2012, 47:598-603.

10. El Moutawakil B, Chourkani N, Sibai M, Moutaouakil F, Rafai M, Bourezgui M, Slassi I: Celiac disease and ischemic stroke. Rev Neuro (Paris) 2009, 165:962-966.

11. Audia S, Duchene C, Samson M, Muller G, Bielefeld P, Ricolfi F, Giroud M, Besancenot JF: Stroke in young adults with celiac disease. Rev Med Interne 2008, 29:228-231.

12. Goodwin FC, Beattie RM, Millar J, Kirkham FJ: Celiac disease and childhood stroke. Pediatr Neurol 2004, 31:139-142.

13. Belfkih R, Souirti Z, Chtaou N, Messouak O, Belahsen F: Accident vasculaire cerebral ischemique revelant une maladie coeliaque. Pan African Med J 2010, 5:2-7.

14. Ludvigsson JF, West J, Card T, Appelros P: Risk of stroke in 28000 patients with celiac disease: a nationwide cohort study in Sweden. J Stroke Cerebrovascular Dis 2012, 21:860-867.

15. Ludvigsson JF, Welander A, Lassila R, Ekbom A, Montgomery SM: Risk of thromboembolism in 14000 individuals with celiac disease. $\mathrm{Br} J$ Haematol 2007, 139:121-127.

16. Ciacci C, Tortora R, Scudiero O, Di Fiore R, Salvatore F, Castaldo G: Early pregnancy loss in celiac women: the role of genetic markers of thrombophilia. Dig Liver Dis 2009, 41:717-720.

17. Baryshnikov EN, Krums LM, Vorobeva NN, Parfenov AL: Lower extremity deep vein thrombosis associated with gluten-sensitivity celiac disease. Ter Arkh 2010, 82:52-54.

18. McNeill A, Duthie F, Galloway DJ: Small bowel infarction in a patient with celiac disease. J Clin Pathol 2006, 59:216-218.

19. Emilsson LE, Smith JG, West J, Melander O, Ludvigsson JF: Increased risk of atrial fibrillation in patients with celiac disease: a nationwide cohort study. Europ Heart J 2011, 32:2430-2437. 
20. Afredj N, Metatla S, Faraoun SA, Nani A, Guessab N, Benhalima M, Bendib SE, Debzi N, Layaida K, Gamar L, Baiod N, Balamane M, Kaddache N, Bounab $\mathrm{N}$, Kecili L, Boucekkine T: Association of Budd-Chiari syndrome and celiac disease. Gastroenterol Clin Biol 2010, 34:621-624.

21. Kremer Hovinga JA, Baerlocher G, Wuillemin WA, Solenthaler M: Deep venous thrombosis of the leg in acquired thrombophiliahyperhomocysteinemia as a sequela of undetected celiac disease. Rev Therapeutique 1999, 56:519-522.

22. Hozyasz KK, Mostowska A, Szaflarska-Poplawaka A, Lianeri M, Jagodzinski PP: Polymorphic variants of genes involved in homocysteine metabolism in celiac disease. Mol Biol Rep 2012, 39:3123-3130.

23. Wilcox GM, Mattia AR: Celiac sprue, hyperhomocysteinemia, and MTHFR gene variants. J Clin Gastroenterol 2006, 40:596-601.

24. Dickey W, Ward M, Whittle CR, Kelly MT, Pentieva K, Horigan G, Patton S, McNulty H: Homocysteine and related B-vitamin status in celiac disease: effects of gluten exclusion and histological recovery. Scand J Gastroenterol 2008, 43:682-688.

25. Casella G, Bassotti G, Villanacci V, Di Bella C, Pagni F, Corti GL, Sabatino G, Piatti M, Baldini V: Is hyperhomocysteinemia relevant in patients with celiac disease? World J Gastroenterol 2011, 17:2941-2944

26. Hallert C, Grant C, Grehn S, Grännö C, Hultén S, Midhagen G, Ström M, Svensson $H$, Valdimarsson T: Evidence of poor vitamin status in celiac patients on a gluten-free diet for 10 years. Aliment Therap 2002, 16:1333-1339.

27. Lerner A, Blank M, Shoenfeld Y: Increased prevalence of autoantibodies in celiac disease. Dig Dis Sci 1998, 43:723-726.

28. Shaoul R, Lerner A: Associated autoantibodies in celiac disease. Autoimmun Rev 2007, 6:559-565.

29. Swissa M, Lerner A, Sasaki T, Sela E, Blank M, Shoenfeld Y: The diverse pathogenic potential of anti-DNA antibodies from various sources to induce experimental systemic lupus erythematosus. Pathobiology 1996, 64:32-39.

30. Shamir R, Shoenfeld Y, Blank M, Eliakim R, Lahat N, Sobel E, Shinar E, Lerner $A$ : The prevalence of coeliac disease antibodies in patients with the antiphospholipid syndrome. Lupus 2003, 12:394-399.

31. Nojima J, Iwatani $Y$, Suehisa E, Kuratsune $H$, Kanakura $Y$ : The presence of anti-phosphatidyle/prothrombin antibodies as risk factor for both arteria and venous thrombosis in patients with systemic lupus erythematosus. Haematologica 2006, 91:699-702.

32. Bertolaccini ML, Gomez S, Pareja JF, Theodoridou A, Sanna G, Hughes GR, Khamashta MA: Antiphospholipid antibody tests: spreading the net. Ann Rheum Dis 2005, 64:1639-1643.

33. Tsutsumi A, Hayashi T, Chino Y, Mamura M, Goto D, Matsumoto I, Ito S, Sumida T: Significance of antithrombin antibodies in patients with systemic lupus erythematosus: clinical evaluation of the antithrombin assay and the antiphosphatidylserine/prothrombin assay, and comparison with other antiphospholipid antibody assays. Mod Rheumatol 2006, 16:158-164.

34. Atsumi T, Koike T: Clinical relevance of antiprothrombin antibodies. Autoimmun Rev 2002, 1:49-53.

35. Atsumi T, leko M, Bertolaccini ML, Ichikawa K, Tsutsumi A, Matsuura E, Koike T: Association of autoantibodies against the phosphatidylserineprothrombin complex with manifestations of the antiphospholipid syndrome and with the presence of lupus anticoagulant. Arthr Rheumatism 2000, 43:1982-1993.

36. Sakai Y, Atsumi T, leko M, Amengual O, Furukawa S, Furusaki A, Bohgaki M, Kataoka H, Horita T, Yasuda S, Koike T: The effects of phosphatidylserinedependent antiprothrombin antibody on thrombin generation. Arthr Rheumatism 2009, 60:2457-2467.

37. Nojima J, Kuratsune $H$, Suehisa E, Iwatani $Y$, Kanakura $Y$ : Acquired activated protein $C$ resistance associated with IgG antibodies against $\beta_{2^{-}}$ glycoprotein I and prothrombin as a strong risk factor for venous thromboembolism. Clin Chem 2005, 51:545-552

38. Nojima J, Kuratsune H, Suehisa E, Kitani T, Iwatani Y, Kanakura Y: Strong correlation between the prevalence of cerebral infarction and the presence of anti-cardiolipin/beta2-glycoprotein I and antiphosphatidylserine/prothrombin antibodies - co-existence of these antibodies anhances ADP-induced platelet activation in vitro. Thromb Haemost 2004, 91:967-976.

39. Descloux E, Durieu I, Cochat P, Vital Durand D, Ninet J, Fabien N, Cimaz R: Pediatric systemic lupus erythematosus: prognostic impact of antiphospholipid antibodies. Rheumatol (Oxford) 2008, 47:183-187.
40. Okuma H, Kitagawa Y, Ishikawa T, Takagi S: Study of phosphatidylserinedependent anti-prothrombin antibody in cerebral infarction. Inter Med 2009, 48:1351-1355.

41. Bertolaccini ML, Atsumi T, Koike T, Hughes GR, Khamashta MA Antiprothrombin antibodies detected in two different assay systems. Prevalence and clinical significance in systemic lupus erythematosus. Thromb Haemost 2005, 93:289-297.

42. Galli M, Luciani D, Bertolini G, Barbui T: Anti- $\beta 2$-glycoprotein I, antiprothrombin antibodies, and the risk of thrombosis in the antiphospholipid syndrome. Blood 2003, 102:2717-2723.

43. Hoxha A, Ruffatti A, Tonello M, Bontadi A, Salvan E, Banzata A, Pengo V, Punzi L: Antiphosphatidylserine/prothrombin antibodies in primary antiphospholipid syndrome. Lupus 2012, 21:787-789.

44. Hoxha A, Ruffatti A, Pittoni M, Bontadi A, Tonello M, Salvan E, Plebani M, Punzi L: The clinical significance of autoantibodies directed against prothrombin in primary antiphospholipid syndrome. Clin Chim Acta 2012, 413:911-913.

45. Walker-Smith JA, Guandalini S, Schmitz J, Shmerling DH, Visakorpi JK: Revised criteria for the diagnosis of celiac disease. Report of the working group of European Society of Pediatric Gastroenterology and nutrition. Arch Dis Child 1990, 65:909-911.

46. Rozenberg O, Lerner A, Pacht A, Grinberg M, Reginashvili D, Henig C, Barak M: A new algorithm for the diagnosis of celiac disease. Cell Mol Immunol 2011, 8:146-149

47. da Rosa Utiyama SR, da Silva Kotze LM, Nisihara RM, Carvalho RF, de Carvalho EG, de Sena MG, de Messias Reason IJ: Spectrum of autoantibodies in celiac patients and relatives. Dig Dis Sci 2001, 46:2624-2630.

48. Petaros P, Martelossi S, Tommasini A, Torre G, Caradonna M, Ventura A Prevalence of autoimmune disorders in relatives of patients with celiac disease. Dig Dis Sci 2002, 47:1427-1431.

49. Cataldo F, Marino V: Increased prevalence of autoimmune diseases in first-degree relatives of patients with celiac disease. J Pedietr Gastroenterol Nutr 2003, 36:470-473.

50. Puurunen M, Vaarala O, Julkunen $H$, Aho K, Palosuo T: Antibodies to phospholipid-binding plasma proteins and occurrence of thrombosis in patients with systemic lupus erythematosus. Clin Immunol Immunopathol 1996, 80:16-22.

51. Bertolaccini ML, Atsumi T, Khamashta MA, Amengual O, Hughes GR: Autoantibodies to human prothrombin and clinical manifestations in 207 patients with systemic lupus erythematosus. J Rheumatol 1998, 25:1104-1108

52. Vaarala O, Puurunen M, Manttari M, Manninen V, Aho K, Palosuo T: Autoantibodies to prothrombin imply a risk of myocardial infarction in middle-aged men. Thromb Haemost 1996, 75:456-459.

53. Palosuo T, Virtamo J, Haukka J, Taylor PR, Aho K, Puurunen M, Vaarala O: High antibody levels to prothrombin imply a risk of deep venous thrombosis and pulmonary embolism in middle-aged men. A nested case-control study. Thrombo Haemost 1997, 78:1178-1182

54. Berthoux E, Fabien N, Chayvialle JA, Ninet J, Durieu I: Adult celiac disease with thrombosis: a case series of seven patients. Role of thrombophilic factors. Rev Med Interne 2011, 32:600-604.

55. Austin A, Campbell E, Lane P, Elias E: Nodular regenerative hyperplasia of the liver and celiac disease: potential role of $\lg A$ anticardiolipin antibody. Gut 2004, 53:1032-1034.

56. D'Agnillo P, Levine JS, Subang R, Rauch J: Prothrombin binds to the surface of apoptotic, but not viable, cells and serves as a target of lupus anticoagulant autoantibodies. J Immunol 2003, 170:3408-3422.

57. Price BE, Rauch J, Shia MA, Walsh MT, Lieberthal W, Gilligan HM, O'Laughlin T, Koh JS, Levine JS: Anti-phospholipid autoantibodies bind to apoptotic, but not viable, thymocytes in a 2-glycoprotein-dependent manner. J Immunol 1996, 157:2201-2208.

58. leko M, Nakabayashi T, Tarumi T, Yoshida M, Naito S, Atsumi T, Koike T: Phosphatidylserine-dependent anti-prothrombin antibody as a new marker for the diagnosis of antiphosphlipid syndrome. Rinsho Byori 2006, 5(4):256-262.

59. Picarelli A, Di Tola M, Sabbatella L, Mercuri V, Pietrobono D, Bassotti G, D'Amico T, Donato G, Picarelli G, Marino M, Borghini R, Centanni M, Gargiulo P: Type 1 diabetes mellitus and celiac disease: endothelial dysfunction. Acta Diabetol 2011 [Epub ahead of print].

60. Foley S, Garsed K, Singh G, Duroudier NP, Swan C, Hall IP, Zaitoun A, Bennett A, Marsden C, Holmes G, Walls A, Spiller RC: Impaired uptake of 
serotonin by platelets from patients with irritable bowel syndrome correlates with duodenal immune activation. Gastroenterol 2011, 140:1434-1443.

61. Coleman NS, Foley S, Dunlop SP, Wheatcroft J, Blackshaw E, Perkins AC, Singh G, Marsden CA, Holmes GK, Spiller RC: Abnormalities of serotonin metabolism and their relation to symptoms in untreated celiac disease. Clin Gastroenterol Hepatol 2006, 4:874-881.

62. Mazzarella G, Stefanile R, Camarca A, Giliberti P, Cosentini E, Marano C, laquinto G, Giardullo N, Auricchio S, Sette A, Troncone R, Gianfrani C: Gliadin activates HLA class 1-restricted CD8+ cells in celiac disease intestinal mucosa and induces the enterocyte apoptosis. Gastroenterol 2008, 134:1017-1027.

63. Lipinski S, Bremer L, Lammers T, Thieme F, Schreiber S, Rosenstiel P. Coagulation and inflammation, Molecular insights and diagnostic implications. Hamostaseologie 2011, 31:94-104.

doi:10.1186/1741-7015-11-89

Cite this article as: Lerner et al:: The thrombophilic network of autoantibodies in celiac disease. BMC Medicine 2013 11:89.

\section{Submit your next manuscript to BioMed Central and take full advantage of:}

- Convenient online submission

- Thorough peer review

- No space constraints or color figure charges

- Immediate publication on acceptance

- Inclusion in PubMed, CAS, Scopus and Google Scholar

- Research which is freely available for redistribution 